\title{
A Study of Reflective Teaching in Professional Development of Secondary School
}

\section{Teachers in Khyber Pakhtunkhwa}

* Muhammad Ayaz, PhD Scholar (Corresponding Author)

** Wazim Khan, Professor

*** Salman Khan, PhD Scholar

\begin{abstract}
Reflective teaching (RT) has globally acknowledged its usefulness to teachers' professional development. This study investigated the consequences of RT concerning teachers' professional development. Objectives of the study were: to search the effect of RT on teachers' professional development; to investigate the extent of $R T$ to be used by teachers; to explore the perception of teachers about RT. This study was qualitative and descriptively analyzed. Researcher used Observation and Interview for data collection. Population was 5537 whereas the Sample consisted of 200 male secondary school teachers. Results of the study were: maximally the teachers had not used the tools of RT and as a result, mostly their teaching had not affected their professional development; mostly teachers were unaware through RT but agreed about the validity of RT to be used in teaching; $R T$ has a great extent to be used by the teachers in the process of teaching. This study endorsed the importance of RT to replace the old traditional methods of teaching through RT. Also, this study will play a dynamic role in spanning the gap between theory with practice.
\end{abstract}

Keywords: Reflective Teaching, Tools of RT, Teachers' Professional Development, Skills, Attitude, Knowledge, Contemplation

\section{Introduction}

Education enlightens an appropriate and right track to each child which facilitates them for acquiring knowledge, skills, standards, and attitude and hence become a sound personality in society, to foster better qualities in a person and to secure the future of a nation. Quality of education can be connected with the quality of a teacher and the quality of good teachers stanched with the eminence of teacher education. Teacher education is a program that develops the teachers' proficiencies and competencies that empower them to fulfill the requirements of the profession and face the global challenges therein. In teacher education, RT is one of the most innovative and reform efforts in the education system (Pedro, 2005).

Reflection can be linked through the ideas of John Dewey. RT is one such reform effort in teacher education that has taken a strong grip in education (Dewey, 1933; Schon, 1983). Reflection is the action or method where the experiences are evoked, specified, considered, and are evaluated (Richards, 1998). RT is a teacher's thinking about what befalls in the classroom and to think about the alternative means so that to achieve the goals and aims (Liu \& Zhang, 2014). Thinking reflectively, are very valuable and it disengages teachers as impulsive and of routine activities (Dewey, 1933). According to Jasper (2003), theory and practice are distinct concepts and RT can bridge the gaps of these concepts of theory and practice. Schon (1983), Fatemipour (2009) along with Kavoshian, Ketabi, and Tavakoli (2013) has labeled the tools of RT, that are: reflection in action (RIA), reflection on action (ROA), teacher's reflective diary (TRD), colleagues' peer observation (CPO), student's feedback (SFB) and audio recording (AR) with video recordings (VR). In RIA, teachers reflect on their actions while teaching the class and in ROA the teachers reflect on their actions after teaching

\footnotetext{
* Department of Education, Qurtuba University of Science \& Information Technology, Peshawar Email: millat_1973@yahoo.com

** Department of Education, Qurtuba University of Science \& Information Technology, Peshawar Email: wazimnj@yahoo.com

*** Department of Education, Qurtuba University of Science \& Information Technology, Peshawar Email: stenonsr@gmail.com
} 
the class. In TRD, the teachers inscribe what has transpired in the class at the end of each lesson (Ferdowsi \& Akbar, 2015).

In TRD, the teachers inscribe what has transpired in the class at the end of each lesson (Ferdowsi \& Akbar, 2015). SFB is using for feedback and to evaluate teaching. It is a very crucial and necessary source and evidence for effective teaching. In CPO, a colleague teacher observes a teacher during their teaching practices. This tool uses for teachers to develop their teaching and for the improvement of students' learning outcomes and their experiences or practices (Bell, 2001). AR can be used for the development of teachers' self-reflective competency (Lockhart, 1994).

The reflective practice is a principal approach for the training and professional development of teachers (Golby \& Viant, 2007). This article favors the importance of RT through teachers' professional development (TPD) and has examined the effects of RT for TPD.

\section{Objectives of the Study}

a. $\quad$ To find out the effect of RT on TPD.

b. $\quad$ To find out the extent of RT in the teaching-learning process (TLP).

c. To find out the perceptions of teachers about RT.

\section{Research Questions of the Study}

a. What is the effect of RT on TPD?

b. What is the scope of RT in TLP?

c. What are the perceptions of teachers about RT?

\section{Literature Review}

Reflection is a term and stretched by John Dewey in their book "How we think" (1910; 1933 \& 1966). He wrote books at the start of the $20^{\text {th }}$ century. The main purpose of teachers' training is facilitation and to make reflection over their teaching practices by following the basic principles of teaching practices (Dewey, 1966). Dewey endorsed that reflection is a significant means for the TPD and stays an important quality for a teacher to have (Ma \& Ren, 2011). In the depth of the $20^{\text {th }}$ century, an American educator, Donald Schon has introduced reflective practices (RP). He wrote about RP and his famous books about RT are "The Reflective Practitioner" and "Educating the Reflective Practitioner". He has introduced many other concepts about reflection that are: knowing in action; RIA and ROA (Visser, 2010).

Killion and Todnem have extended the ideas of Donald Schon and introduced "reflection for action". Fatemipour (2009), Kavoshian, Ketabi, and Tavakoli (2013) has categorized the other tools for RT, which are: reflective diary of teachers, peer observation of colleagues, student's feedback, and audio with video recordings.

Plenty of models for RT have been presented by different authors, in different periods. Borton (1970) was a teacher, has introduced a model of RT and described them in their book "Reach, Touch and Teach". Kolb (1984) has introduced a model about RT and is known as "Kolb's Reflective Model". Graham Gibbs (1988) has labeled a reflective model and known as the "Reflective Cycle Model" and introduced them in his book "Learning by Doing".

Through Farrell (2004), different descriptions of RT have illustrated its different levels. These levels are labeled as: Technical Rationality, Contextual Level, and Critical Reflection.

The concept of RT can be found for the last two decayed. In the context of reflection, many studies have been counted in Pakistan. Ehsan (2011), Hajira and Shamsa (2012), Iqbal (2015), and Hussain and Khan (2016) etc. have conducted their studies in Pakistan. Many developed countries have adopted and are practicing RP. In the USA and UK, the RP can be seen clearly (Posner, 1985; Ashcroft \& Griffiths, 1989).

Despite due importance, the RT has not well-recognized in Pakistan. There are many reasons which attribute this disappointment. The teachers are using the old traditional methods of teaching and are unaware of RT (Rarieya, 2005). The courses offered for teachers cannot justify the current demands of teaching practices and cannot produce the capabilities for critical thinking. The teachers are unaware of books, theories, and other literature, related to RT and causes the unfamiliarity of teachers with RT (Khan, Fazal, Amin, \& Khan, 2018).

The RP is essential and plays a rudimentary role for capable professionals and training is important for the professional education of teachers, in the context of RT (Schon, 1983 \& 1987). In RP the teachers develop new understandings about their self and professional practices, through their experiences. Ur (1999), expressed that reflection on daily events of the classroom is the main 
principle and a base for the professional growth of teachers. Reflection is an approach where teachers commit to continuous learning (York-Barr, et al., 2001). RT is an innovative approach that fosters the capabilities of a teacher in the context of effective teaching and professional development. RT bridge the gap between theory and practice among the teachers.

Many studies had been conducted in the context of RT. Pedro (2005) has conducted a qualitative study and claimed that RP affects the knowledge of prospective teachers. Roadman (2010) determined that RP affects the decision-making skills of teachers and develop a student-centered approach in teaching. Iqbal (2015), concluded that the tools of RT effect the TPD. He also investigated that the teachers use the tools of RT even though unaware of their practices.

\section{Research Methodology}

This study was qualitative and descriptively analyzed. The qualitative method is a research method where non-numerical data collected by the researchers (Babbie, 2014). Observation and Interview are the tools used for this study, for the sake of desired objectives. This study is based on the philosophy of constructivism where Observation and interview can be used as research tools (Kalender, 2007). The percentage is used as a statistical tool for the findings of the study. In a qualitative study, the data can be analyzed descriptively by using statistical tools e.g. percentage to expose the definite features about the phenomena that are to be studied (Fraenkel, Wallen \& Hyun, 2011). RIA, ROA, TRD, SFB, $\mathrm{CPO}$, and AR, are six tools of RT, used by the researcher, for this study. In Pakistan, there are professional standards for teachers, which were thought-out, and the researcher selected only five of them, which are: instructional planning and strategies, subject matter knowledge, knowledge of ethical values, effective communication, and assessment. The researcher studied each tool of RT for the professional development of teachers, in the context of knowledge, attitude, and skills and the knowledge, attitude and skills, studied in the context of particular professional standards. To explore the comebacks of proposed teachers, the researcher used a three-point scale: "Yes", "Somewhat", and "No". The results of whether tools of RT affected the TPD or not, depended upon the percentage of responses. Constructing the format for observation and interview, the researcher has taken many reviews with the help of supervisor, professors, and some other experts.

\section{Population}

Male Secondary School Teachers (SST) were respondent teachers and consisted of SST-Science group and SST-General group. The researcher selected the teachers from government high schools (GHS) and government higher secondary schools (GHSS) from four districts Peshawar, Mardan, Nowshera, and Charsadda. The population for this study was 5537 male SSTs (EMIS, ASC-2016-17).

\section{Sample and Sampling Technique}

In four selected districts, the total number of male SSTs were 1225 (EMIS, ASC-2016-17). The sample of the study was 200 teachers and selected as of four districts. Only male teachers were selected as respondents because of cultural restrictions in Khyber Pakhtunkhwa. The researcher used the Convenient Sampling Technique. It consists of a group of entities that are reachable and manageable for the study.

\section{Data Analysis}

\section{Descriptive analysis of Observation}

For this study, the researcher selected the Reflective tools and professional standards. The researcher analyzed tools of RT, descriptively and searched the effect of RT for TPD, in the context of knowledge, attitude, and skills through selected professional standards.

Table 1: Effect of RT in TPD

\begin{tabular}{lllllllll}
\hline Professional tool & Responses & RIA & ROA & TRD & SFB & CPO & AR & Total \\
\hline Knowledge & Yes & $82.3 \%$ & $64.9 \%$ & $2.3 \%$ & $64.9 \%$ & $1.6 \%$ & $0.9 \%$ & \\
Attitude & Yes & $79.2 \%$ & $60.5 \%$ & $2.5 \%$ & $60.3 \%$ & $1.7 \%$ & $1.1 \%$ & \\
Skills & Yes & $59.3 \%$ & $40.2 \%$ & $1.5 \%$ & $37.8 \%$ & $1.2 \%$ & $0.9 \%$ & $\mathbf{3 1 . 3 \%}$ \\
Total & & $73.3 \%$ & $55.2 \%$ & $2.1 \%$ & $54.3 \%$ & $1.5 \%$ & $0.97 \%$ & $\mathbf{3} \%$ \\
Knowledge & S.W & $82.3 \%$ & $10.2 \%$ & $1.4 \%$ & $9.1 \%$ & $0.9 \%$ & $0.7 \%$ & \\
Attitude & S.W & $11.1 \%$ & $14.4 \%$ & $1.9 \%$ & $13.7 \%$ & $0.7 \%$ & $0.5 \%$ & \\
Skills & S.W & $30.4 \%$ & $33.0 \%$ & $0.9 \%$ & $33.8 \%$ & $1.1 \%$ & $0.7 \%$ & $\mathbf{9 . 6 \%}$ \\
Total & & $16.7 \%$ & $19.2 \%$ & $1.4 \%$ & $18.9 \%$ & $0.9 \%$ & $0.63 \%$ & \\
Knowledge & NO & $82.3 \%$ & $24.9 \%$ & $96.3 \%$ & $26.0 \%$ & $97.5 \%$ & $98.4 \%$ & \\
Attitude & NO & $9.7 \%$ & $25.1 \%$ & $95.6 \%$ & $26.0 \%$ & $97.6 \%$ & $98.4 \%$ & \\
Skills & NO & $10.3 \%$ & $26.8 \%$ & $97.6 \%$ & $28.4 \%$ & $97.7 \%$ & $98.4 \%$ &
\end{tabular}


Total

$\begin{array}{lllllll}9.6 \% & 25.6 \% & 96.5 \% & 26.8 \% & 97.6 \% & 98.4 \% & \mathbf{5 9 . 1 \%}\end{array}$

Table 1 exemplified the effect of RT in TPD. According to this table, the majority of the proposed teachers performed RIA, ROA, and SFB and generally affected their professional development while teachers performed TRD, CPO, and AR and comparatively less affected their professional development in the context of knowledge, attitude, and skills. As a whole, the results have approved that most teachers have not performed RT and henceforth RT has not affected TPD. The results approved that the respondent teachers performed RT and affected $31.3 \%$, affected somewhat $9.6 \%$ and not affected $59.1 \%$, TPD.

\section{Descriptive Analysis of Interview}

In the interview, the researcher asked questions from assigned teachers and searched the teachers' perception about awareness, validity, and extent of each tool of RT at SSL, in TLP.

Table 2: Teachers' Perception about Awareness of RT

\begin{tabular}{llll}
\hline Reflective Tool & Yes & S.W & No \\
\hline RIA & $15.0 \%$ & $1.5 \%$ & $83.5 \%$ \\
ROA & $14.5 \%$ & $0.5 \%$ & $85.0 \%$ \\
TRD & $20.0 \%$ & $8.5 \%$ & $71.5 \%$ \\
SFB & $93.0 \%$ & $1.0 \%$ & $6.0 \%$ \\
CPO & $21.0 \%$ & $1.0 \%$ & $78.0 \%$ \\
AR & $99.0 \%$ & $0.0 \%$ & $1.0 \%$ \\
Total & $43.7 \%$ & $2.1 \%$ & $54.2 \%$ \\
\hline
\end{tabular}

Table 2 declared that, as a whole, most of the teachers were unaware of RT at SSL. Results of the above table clarified that proposed teachers were aware $43.7 \%$, aware of somewhat $2.1 \%$, and unaware $54.2 \%$, around RT at SSL.

Table 3: Teachers' Perception about validity of $R T$

\begin{tabular}{llll} 
Reflective Tool & Yes & S.W & No \\
\hline RIA & $77.0 \%$ & $6.5 \%$ & $16.5 \%$ \\
ROA & $72.0 \%$ & $19.0 \%$ & $9.0 \%$ \\
TRD & $59.5 \%$ & $15.0 \%$ & $25.5 \%$ \\
SFB & $97.5 \%$ & $0.0 \%$ & $2.5 \%$ \\
CPO & $57.5 \%$ & $16.5 \%$ & $26.0 \%$ \\
AR & $57.0 \%$ & $13.5 \%$ & $29.5 \%$ \\
Total & $\mathbf{7 0 . 1 \%}$ & $\mathbf{1 1 . 7 \%}$ & $\mathbf{1 8 . 2 \%}$ \\
\hline
\end{tabular}

The result of table 3 declared that most of the teachers remain agreed that RT is valid and can be used by teachers in TLP. Results professed the validity of RT and to be used $70.1 \%$, used of somewhat $11.7 \%$ and not to be used $18.2 \%$, by teachers at SSL in TLP.

Table 4: Extent of RT to be used, in TLP

\begin{tabular}{llll}
\hline Reflective Tool & Yes & S.W & No \\
\hline RIA & $91.3 \%$ & $2.5 \%$ & $6.2 \%$ \\
ROA & $71.5 \%$ & $5.8 \%$ & $22.7 \%$ \\
TRD & $24.5 \%$ & $4.7 \%$ & $70.8 \%$ \\
SFB & $48.3 \%$ & $1.5 \%$ & $50.2 \%$ \\
CPO & $48.3 \%$ & $1.5 \%$ & $50.2 \%$ \\
AR & $82.7 \%$ & $2.5 \%$ & $14.8 \%$ \\
Total & $\mathbf{6 1 . 1 \%}$ & $\mathbf{3 . 1} \%$ & $\mathbf{3 5 . 8 \%}$ \\
\hline
\end{tabular}

In table 4, the results illustrated the extent of RT in TLP. Results professed that RT can be used at SSL in TLP. The fallouts of the table approved the possibility of RT, to be used $61.1 \%$, used somewhat $3.1 \%$, and not to be used $35.8 \%$, by teachers at SSL in the process of teaching.

Results

According to table 1, the majority of proposed teachers performed RIA, ROA, and SFB and affected their professional development in the context of knowledge, attitude, and skills. Also, TRD, CPO, and AR performed by teachers but, comparatively less, affected their professional development in the context of knowledge, attitude, and skills. The collective result about RIA, ROA, TRD, SFB, CPO, and AR, professed that most of teachers had not performed most of these tools and hence not effected the professional development of teachers, during teaching practices. Table 2 uncovered the perceptions of proposed teachers about reflective tools and present that majority of teachers were 
unaware of RIA, ROA, TRD, SFB, CPO, and AR. Table 3 exposed the perception of teachers about tools of RT and the majority of teachers have proposed that "RIA, ROA, SFB and AR" are possible and valid to be used for the improvement of professional development of teachers. Table 4 recommended the extent of reflective tools RIA, ROA, SFB, and AR and identified that RIA, ROA, SFB, and AR are possible to be used for the professional development of teachers in TLP.

\section{Discussions}

Pedro (2005), determined that RP affects the knowledge of prospective teachers. According to Gheith and Aljabri (2018), there is a significant relationship between teachers' attitude and their professional development through RP. Pandey (2012) determined that RT can improve the teaching skills of teachers and as well can develop their instructional practices. In this study, the results exposed that teachers have performed RIA, ROA, and SFB, in teaching and affected TPD in the context of knowledge, attitude, and skills of particular professional standards.

The study of, Khan, Fazal, and Amin (2018), claimed that the teachers in Pakistan, are unfamiliar with RT and even though most of the teachers are unaware through books and authors. Also, teachers are unaware of theories and other literature about reflection. This study has searched the teachers' perception about RT and found that the majority of teachers are unaware of the tools of RT.

Schon (1983), stated that someone become a researcher when performed RIA. Then he or she does not count on, others' categories or reputable theories and techniques and thus develops new theories of the unique case by their self. Similarly, ROA can develop, modify or improve the teaching practices, after doing a task. According to Husain and Khan (2016), SFB is the best and common source for evaluation of teaching. Kavoshian, Ketabi, and Tavakoli (2013) comprehended that the teachers can identify their strengths and weakness in teaching through audio and video recording. By Korthagen (2001a), teachers' knowledge can be developed by making reflection on experiences. This study searched the perception of proposed teachers about RT and their tools. Most of the teachers had recommended that "RIA, ROA, SFB, and AR" are possible and valid to be used for TPD in TLP. Also, the study searched the extent of RIA, ROA, SFB and AR, in TLP and acknowledged that RIA, ROA, SFB, and AR are conceivable for TPD in TLP.

\section{Conclusions}

Through observation, results concluded that most teachers have performed RIA, ROA, and SFB in teaching and hence affected TPD at SSL. Furthermore, most of the proposed teachers have not performed TRD, CPO, and AR during teaching and as a result, not affected TPD at SSL. The researcher investigated the effect of RT for TPD by contemplating RIA, ROA, TRD, SFB, CPO, and AR, collectively. Results of the study concluded that most of the reflective tools have not been used by teachers during teaching and as a result, RT has not affected the professional development of teachers.

Through the interview, the teachers' perception about RT, has been investigated. Based on the consequences of the study, the researcher concluded that most of the respondent SSTs were unaware of RT but the majority of respondent teachers agreed that RT is valid to be used in TLP.

Also, the researcher has investigated the extent of RT that can be used in the process of teaching. The findings of the study exposed that RIA, ROA, SFB, and AR have been used by teachers during teaching and hence concluded that reflective tools RIA, ROA, SFB, and AR are possible to be used by teachers in TLP.

\section{Recommendations}

The study exposed that most of the teachers are unaware of RT and their tools. Therefore, curriculum designers and textbook developers should consider the due importance of RT along with their tools. At each level, the curriculum of teacher education should be consisted of content about RT, for the awareness, understanding, and use of RT and their tools.

The reflective diary stays its usefulness in teaching but mostly the teachers are not using it in teaching. During training, the importance of TRD should be emphasized. Teachers should be stimulated to maintain a diary for the records of their previous experiences about teaching. The School's principal should motivate their teachers to maintain a diary and makes it compulsory.

$\mathrm{CPO}$ is very valuable and significant in getting experiences from professionals, experts, specialists, senior school teachers, and other colleagues. Therefore, there should be an environment of 
collaboration and confidence among the teachers. The junior and senior teachers should encourage and cooperate.

AR is very helpful in TLP. It is a practical, easy and manageable reflective tool and can be used in TLP. During training, the teachers should be taught about AR and provide them training about, how to practice it as a reflective tool in TLP.

\section{References}

Ashcroft, K, \& Griffiths, M. (1989). Reflective teachers and reflective tutors: School experience in an initial teacher education course. Journal of Education for Teaching, 15(1), 35-52.

Babbie, E. (2014). The Basics of Social Research (6th Ed.). Belmont, California: Wadsworth Cengage learning.

Bell, M. (2001). Supported Reflective Practice: A Programme of Peer Observation and Feedback for Academic Development. International Journal for Academic Development, 6(1), 29-39. doi: 10.1080/13601440110033643.

Borton, T. (1970). Reach, Touch, and Teach: Student Concerns and Process Education. New York: McGraw-Hill.

Dewey, J. (1933). How we think. Washington: University of Wisconsin Press. Education Management Information System (EMIS), All School Census Report (ASC-2016-17). Peshawar. Retrieved from: http.wwww.kpese.gov.pk/EMIS/html.

Farrel, T. S. (2004). Reflective practices in action: 80 reflection breaks for busy teachers. California: Corwin Press

Fatemipour, H. (2009). The Effectiveness of Reflective Teaching Tools in English Language Teaching. Modern Thoughts in Education, 4(4), 73-92.

Ferdowsi, M., \& Akbar, A. (2015). The Effects of Reflective Teaching on Teachers' Performance. International Journal of Educational Investigations. 2(6), 20-31.

Fraenkel, J., Wallen, N., \& Hyun, H. (2011). How to Design and Evaluate Research in Education (8th Edition). New York, NY: McGraw-Hill.

Gibbs, G. (1988). Learning by Doing: A Guide to Teaching and Learning Methods. Oxford: Oxford Brookes University Further Education Unit.

Gheith, E., \& Aljabri, N. (2018). Reflective Teaching Practices in Teachers and their Attitudes toward Professional Self- Development. International Journal of Progressive Education, 14(3), 160179.

Golby, M., \& Viant, R. (2007). Means and Ends in Professional Development. Teacher Development, $11(2), 237-243$.

Husain, M., \& Khan, S. (2016). Students' feedback: An effective tool in teachers' evaluation system. International Journal of Applied and Basic Medical Research, 6(3), 178-181. doi: 10.4103/2229-516X.186969

Iqbal, M. Z. (2015). A study of reflective practices for professional development of the prospective teachers in Pakistan: Islamabad: Department of education faculty of social sciences international Islamic university.

Jasper, M. A. (2003). Beginning reflective practice: Foundations in Nursing and Health Care Series. Cheltenham, UK: Nelson Thornes Ltd.

Kalender, M. (2007). Applying the Subject "Cell" Through Constructivist Approach during Science Lessons and the Teacher's View. Journal of Environmental \& Science Education 2(1): 3-13.

Kavoshian, S., Ketabi, S. \& Tavakoli, M. (2013). Self-Evaluation through Videotaping as an Alternative Mode of Teaching. The Iranian EFL Journal, 9(2), 272-285

Khan, M. I., Fazal, S., \& Amin, M. (2018). Reflection in Teacher Education Programmes in Pakistan and the UK: A Comparison. Journal of ResPrentice-Halllections in Education. 8(2), 132 138.

Kolb, D. A. (1984). Experiential Learning: Experience as the Source of Learning and Development. Englewood Cliffs, NJ: Prentice Hall.

Korthagen, F. A. J. (2001a). Linking Practice and Theory: The Pedagogy of Realistic Teacher Education. New Jersey: Lawrence Erlbaum Associates, Inc.

Liu, L. \& Zhang, Y. (2014). Enhancing Teachers' Professional Development through Reflective Teaching. Theory and Practice in Language Studies. 11(4), 2396-2401. 
Lockhart, C. (1994). Reflective Teaching in Second Language Classrooms. Cambridge: Cambridge University Press.

Ma, J., \& Ren, S. (2011). Reflective Teaching and Professional Development of Young College English Teachers-From the Perspective of Constructivism. Theory and Practice in Language Studies, 1(2), 153-156. doi:10.4304/tpls.1.2.153-156

Pandey, S. R. (2012). Reflective Practices: A Gateway to Professional Development. Journal of NELTA, 17(1-2), 40-49.

Pedro, J. Y. (2005). Reflecting in teacher education: Exploring pre-service teachers' meaning of reflective practices. Reflective Practice, 6(1), 49-66.

Posner, G. J. (1985). Field Experience: A Guide to Reflective Teaching (4th Ed.). White Plains, New York: Longman.

Rarieya, J. (2005). Promoting and Investigating Students' Uptake of Reflective Practice: A Pakistan case. Reflective Practice, 6(2), 285-294. doi: 10.1080/14623940500106518.

Richards, J. C. (1998). Beyond training. Cambridge: Cambridge University Press.

Roadman, G. J. (2010). Facilitating the teaching-learning process through the reflective engagement of pre-service teachers. Australian Journal of teacher education, 35(2), 20-34.

Schon, D. A. (1983). The reflective practitioner: how professionals think in action. New York: Basic Books.

Ur, P. (1999). A Course in Language Teaching: Practice and Theory. Cambridge: Cambridge University Press (CUP).

Visser, W. (2010). Schon: Design as a reflective practice. Collection, Parsons Paris School of art and design, Art + Design and Psychology, pp. 21-25.

York-Barr, J., Sommers, W.A., Ghere, G.S., \& Montie, J. (2001). Reflective practice to improve schools: An action guide for educators. Thousand Oaks, CA: Corwin Press, Inc. 